\title{
SUHARTO AND MAHATHIR, POLITICAL SURVIVAL AND THE ASIAN ECONOMIC CRISIS IN 1998: A HISTORICAL REFLECTION
}

\author{
${ }^{1}$ Blake Respini \& ${ }^{2}$ Herdi Sahrasad \\ ${ }^{1}$ Department of Political Science, San Francisco State University, California, \\ USA \\ ${ }^{2}$ Center for Islam and State Studies, Faculty of Falsafa and Civilizations, \\ Paramadina University, Jakarta, Indonesia \\ (herdi.nurwanto@paramadina.ac.id)
}

\begin{abstract}
President Suharto of Indonesia fell from power during the Asian Financial Crisis of 1998. A political crisis erupted which encouraged students and the international community, especially the West to urge him to resign. After 1998 the fall of Suharto afforded the opening for reform and democracy. By contrast, in Malaysia, Prime Minister Mahathir's UMNO regime withstood the brunt of the economic crisis and managed to achieve a soft economic landing avoiding a political crisis on the scale experienced by the people of Indonesia. Nevertheless, Malaysia under the current government postMahathir should recognise that the change to democracy sooner or later might happen. Even in Malaysia, following his electoral victory, Mahathir worked to reimpose authoritarian control, which had been weakened after the 1999 election. In 2000, dissidents were jailed, and journalists we muzzled, leading liberal western commentary like The Economist to criticise the reassertion of single party rule. This paper examines how despite the economic crisis Mahathir had the political capacity to maintain a version of competitive authoritarianism sustained by his successors.
\end{abstract}

Keywords: Suharto, Mahathir, authoritarian crisis, reform, democracy, change, Asia, Malaysia, Indonesia, election 


\section{Introduction}

On May 21, 1998, after months of violence, political uncertainty and economic turmoil, President Suharto of Indonesia resigned, thus unceremoniously ending 33 years of one-man rule. Only a few hundred miles away, across the Malacca Strait, Malaysian strongman Mahathir Mohamad was also being battered by the economic crisis that had started the previous year. Within months of Suharto's fall, Mahathir launched an attack on the International Monetary Fund and arrested his top advisor and would-be successor Anwar Ibrahim, thus creating a new level of crisis in Malaysia. As the international community winced at the turn of events, student demonstrations erupted in Malaysia and journalists around the globe considered whether Mahathir would be the next Asian dictator to fall. This seemed likely as Malaysia, and Indonesia was similar in many respects. Both were Muslim nations with Malay majorities and large economically significant Chinese minorities. Furthermore, both had shared decades of authoritarian rule mixed with impressive economic development when the economic crisis exploded in August of 1997 devastating both economies. However, unlike Suharto, Mahathir would weather the storms and survive to rule on until his voluntary retirement in 2003.

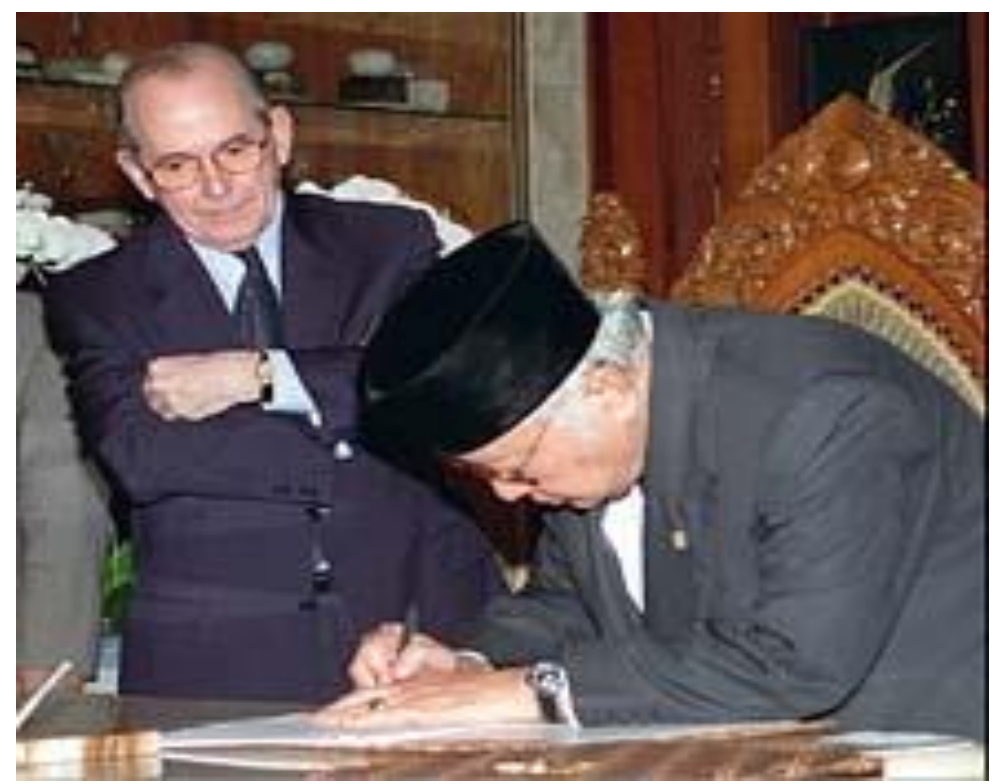

Figure 1: Suharto Signs the IMF Agreement (Agence France-Presse) 
While economic differences are often used to explain the two leader's dissimilar fates, this essay will show that political factors played at least as big a role and that the greater degree of political freedom that existed in Malaysia allowed Mahathir to outlast his Indonesian counterpart. Though both led clearly authoritarian governments, in Malaysia was unique in four ways. Its power was more widely dispersed within the ruling party, its electoral politics involved real competition, its military stayed out of the political process, and its Chinese minority was constructively included in the political affairs. All of these factors, which made Malaysia politically free and inclusive, contributed to Mahathir's survival, whereas their absence in Indonesia contributed to Suharto's collapse. The irony of this is that when the economic crisis hit both countries in 1997, only Indonesia was able to seize the window of opportunity for change brought by the crisis and transform its political system. In the end, Malaysia's greater level of freedom led it to become less free and democratic than Indonesia is today.

\section{Two Peas in a Pod?}

In many ways, Indonesia and Malaysia are twins. The Indonesian archipelago sits due East of the Malaysian peninsula and even includes Borneo, half of which belongs to Malaysia. Geographically, the nations are so close that in 1997, a bridge was planned to link Sumatra with Malaysia, which would have physically and symbolically linked these two Malay peoples (Eklof, 1999, p. 101). The Malay settled the land of both countries during the 6th century, and today Malays form the vast majority of both countries and share a language with common roots. During the 14th century, the presence of Muslim traders led to the conversion of the indigenous population, providing both nations with an Islamic base. However, during their colonial era, large numbers of Chinese were brought into both nations to provide the services demanded by the colonial leaders. Thus, today both countries have significant Chinese populations that due to their wealth and foreign status serve as a backdrop to the political and social battles that dominate each country (Warshaw, 1990).

Upon the departure of their colonial rulers, both countries had to overcome challenges posed by their physical and cultural diversity. Indonesia was unified by Sukarno under his national vision known as "Pancasila", which attempted forge a national consensus based on God, humanity, unity, democracy, and social justice (Eklof, 1996, p. 6). However, his "Guided Democracy" set the basis of the authoritarian rule that existed for the next half century. In 1965, after a military coup and brutal attacks on its Chinese 
community, which left up to 400,000 Chinese dead, General Suharto who opened Indonesia to the West (Warshaw, 1990, p. 227) replaced the left-leaning Sukarno. While he encouraged trade, foreign investment, and economic development, he also maintained strict authority over the political environment as Pancasila became a national ideology that served to limit debate in the name of moral responsibility to the nation (Elson, 2001, p. 188).

Malaysia, likewise, went through a period of political development that left it with an authoritarian leader who formed a national vision for the country and promoted economic development through international trade. Tunku Abdul, Malaysia's first prime minister, led the Alliance Party which tried to unite Malaysia's main ethnic groups while increasing the power and economic well-being of the Malay population. However, in 1969, just four years after the purging of the Chinese in Indonesia, ethnic riots resulting in the death of two hundred people in Malaysia led to a restructuring of its political system (Elson, 2001, p. 23). A state of emergency was declared, and the following year Tunku resigned. The UMNO, a coalition party that United Malays, became the ruling party, selecting two prime ministers before settling on Mahathir bin Mohamad in 1981.

Once in power, both Mahathir and Suharto followed similar brands of authoritarianism and pro-Western economic development. Both countries experienced growth that counted them among the Asian Tigers who were noted for their stunning economic growth and their growing role on the international economic scene (Borthwick, 1992). However, while both countries allowed for elections and even opposition parties to exist, only one party had true power in each country and both leaders tightly controlled the press and jailed opponents to insure to insure that they stayed in power. Both regimes also became known for their cronyism, nepotism, and corruption. However, as U.S. allies in the Cold War, there was little international pressure for them to change. Both cooperated with the West regarding economic openness, while on the home front legitimacy, was maintained by positive economic performance (Borthwick, 1992; Macintyre, 2001, p. 95).

Ironically, their very success suggested that the days of these dictators were numbered. Elson's history of Suharto's reign echoes Samuel Huntington's The Third Wave, when he points out that "prosperity is the great liberalising force" (Elson, 2001, p. 294/Huntingon, 1991, p. 62). Both works point out that a growing middle class is less likely to tolerate a lack of freedom and indeed cries for reform could be heard in both countries in the midst of their growing prosperity. However, as long as the economies performed, these cries led to little change. In the summer of 1997, both leaders were riding high 
and seemingly entrenched in power for a long as they chose. In March of 1997, Asia Week listed Mahathir and Suharto as number two and three, respectively, of the 50 most powerful men in Asia (4/10/1997).

However, the economic crises that burst onto the scene that August put enormous pressure on both regimes as both leaders tried to deal with the collapse of their currencies and the domestic hardship that resulted. At first, Suharto looked like he might ride out the storm, being reinstated as president for a new 5-year term in March of 1998. However, within months, riots across the country left thousands dead as Suharto's attempts to quell opposition failed. Eventually, elites within the government and the military abandoned him leaving him no option but to resign (Elson, 2001). This seemed like a harbinger as to what would happen in Malaysia. In fact, students in Malaysia took up the called of "Reformasi" which had been the rallying cry in Indonesia (Felker, 1998). Just a month after Suharto's resignation, Mahathir sacked his deputy prime minister, Anwar Ibrahim, who had been critical of his economic policies. Anwar's arrest and apparent beating led to international calls for reform. It looked like Mahathir's days were a number. Even The Economist wrote:

The old order, established in the 1960s, is fading, and the forces of "reform" are battling those of reaction. Reformasi, the catch-all slogan of the movement that helped unseat President Suharto of Indonesia in May, has now been taken up by Mr Anwar's supporters. It encompasses a drive against corruption and a change to a more responsive, pluralist political system.

$(10 / 10 / 98)$

Of course, those who predicted regime change in Malaysia were wrong; thus a closer look at the two countries is required to explain the different paths each regime took.

\section{The Matter of Economics vs. Politics}

One possible explanation for the different outcomes in Malaysia and Indonesia is the degree to which each was affected by the economic crisis, for there is no doubt that the suffering was greater in Indonesia. To start with, World Bank data shows that while the Malaysian ringgit depreciated by about $100 \%$, the rupiah fell by nearly $600 \% .^{1}$ This meant that Indonesians could not buy the foreign goods they depended on, and businesses went bankrupt, as they could not pay off their loans. Furthermore, Indonesia's rates of inflation, 
unemployment, and GDP decline were all significantly more severe than Malaysia's (See Figure 1).

Figure 1
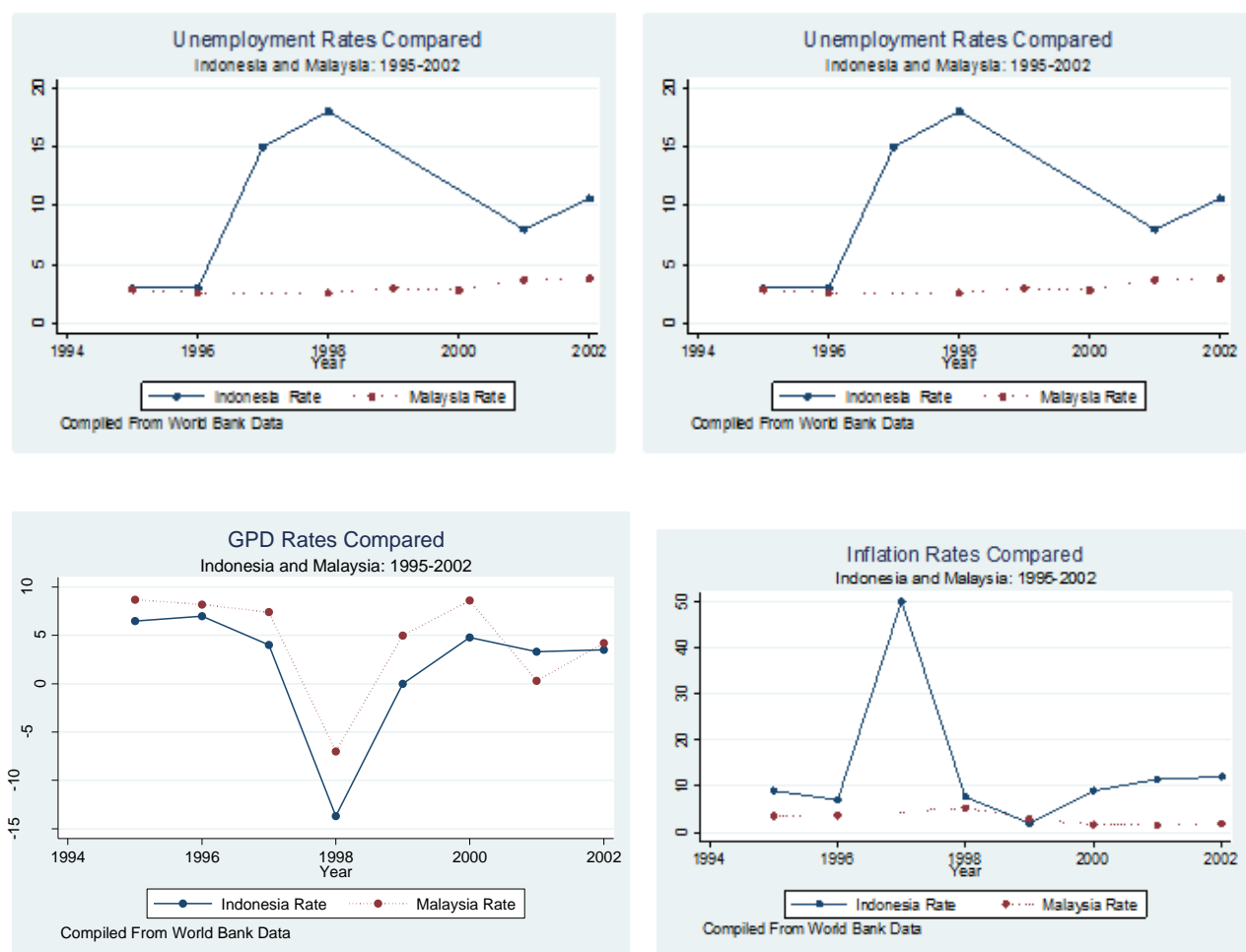

By the end of 1997, millions of jobs had been lost in Indonesia as the per capita income of Indonesians dropped by over $60 \%$, and unemployment rose to over $18 \%$. By comparison, Malaysia's drop in GDP was closer to $10 \%$, and unemployment was never above $4 \%$. While hundreds of businesses went bankrupt in Malaysia and the stock market dropped $80 \%$, in Indonesia food prices rose so dramatically that many could not even afford rice (Business Week, 1997, Lane, 2005, Milne, 1999, p. 176, Elkof, 1999, p. 117).

While these economic differences were substantial, focusing on the economic crisis misses a few things. First, though Indonesia's economy was in worse shape, the situation in Malaysia was certainly severe enough to also potentially bring a government down all otherthings being equal. Dani Rodrick points out that both Thailand and South Korea experienced regime change because of the crisis even though their economic shocks were not particularly more severe than Malaysia's (Rodrick, 1999, p. 92). For example 
Thailand's greatest annual decline in GDP in was only $1.5 \%$ more than Malaysia's while South Korea's decline was $0.2 \%$ less than Malaysia's (See Figure 2). Likewise, inflation and unemployment in Malaysia were only slightly worse than Thailand's and South Korea's. Thus, the milder severity of the economic crisis alone seems insufficient to explain regime stability. Furthermore, another economic factor suggests that Indonesia should have been more stable than Malaysia. This is the issue of the income gap, which was less severe in Indonesia than Malaysia. ${ }^{2}$ In 1997, The Economist took note of this and went on to suggest that political issues were the critical factor in the regime change, saying that it was the "justice gap, not the economic gap" that people objected to $(7 / 26 / 97)$.

Figure 2:

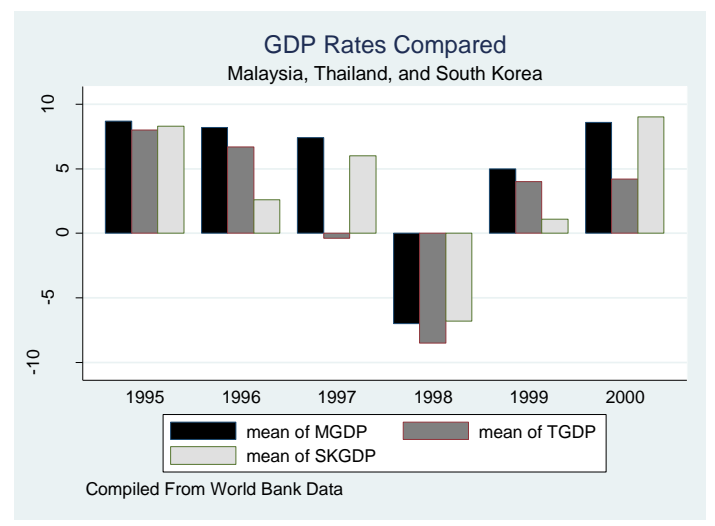

Finally, it is important to go beyond economics to see the role politics played in the contributing to the severity of the economic downturn in each country. Andrew MacIntyre's study of how the political differences between the Philippines, Thailand, Malaysia and Indonesia affected the depth of the economic crisis in each country points out that the greater concentration of power in Indonesia compared to Malaysia made Indonesian investors nervous, contributing to that country's greater economic decline (2001). Economist Dani Rodrick went even further by creating a conceptual framework for assessing the impact of politics on the economic crisis with the following postulation:

change in growth $=$ external shocks $x$ latent social conflict

institutions of conflict management 
This holds that economic declines will be proportionally less in response to external shocks the less social conflict there is and the more effective the social institutions are. He then explained that the shocks suffered by the nations of East Asia were similar but that differing levels of social conflict and differing degrees of responsiveness by institutions of conflict management resulted in the differing severity of the crisis in each country $(1999$, p. 82). While he does not discuss Malaysia specifically, he rightly points out, as this paper will clearly show, that Indonesia's deep levels of social conflict and poor institutions strongly exacerbated the crisis there (1999, pp. 93-94).

Thus, while the economic downturn may have provided fuel for political instability in both Indonesia and Malaysia, we will see that critical differences in their levels of political freedom played the key role in the ability of each country's regime to survive. The broad political differences between the two countries can be seen in their relative Freedom House ratings whereby Freedom House rates Indonesia as "not free" in 1997 while Malaysia deemed as "partly free". On their 7 point index (made up of nine separate factors), a rating of 7 is the least free while one is the freest. Though both earned dismal ratings of 5 for civil rights, Figure 3 shows that before the crisis Indonesia was at rock bottom on the political rights scale while Malaysia earned a 5, representing its greater degree of freedom (Freedom House, 2006).

The difference in these ratings is not surprising when one looks at the varying degree of voice each regime gave others within their authoritarian system. In both regimes, the centre of power rested with the leader, but if we were to draw concentric circles emanating from each of these leaders, we would see three levels of greater inclusive in Malaysia. The first circle involves the power the leaders gave to advisors within the regime; the second circle contains the role they allowed opposition parties to play and the third ring circumscribes the degree to which ethnic minorities were heard from and accommodated. Ultimately, Malaysia's greater breadth of power, and thus freedom, in all three areas allowed Mahathir to weather the crisis brought on by the economic crisis, which got the best of Suharto.

\section{Indonesia's One Man Show vs. Malaysia's Consultative Authoritarianism}

A key difference between the Suharto and Mahathir regimes was the degree to which each leader relied on and empowered key advisors. In the end, when the economic crisis hits, this difference will leave Suharto standing alone and naked while Mahathir will successfully be able to deflect blame away from 
himself. This will be examined both in terms of how they handled their top advisors as well as their relations with their militaries.

\section{Suharto's Single-handed Rule and the Economic Crisis}

Unlike Malaysia, when Indonesia was hit by the economic crisis of 1997, its leader became practically the sole focus of the problem. Part of the reason for this was the degree to which Suharto concentrated power within himself. As one senior government official put it, "He sees himself as a Javanese king, and a Javanese king just doesn't divide power" (Kristof, 1998). While there was certainly opposition to Suharto within his regime, vocal opponents tended to be quickly weeded out, and his ministers mostly remained differential to him. Elson says that by the late 1980's he was "in ways never before experienced, alone in his weighty responsibilities" (2001, p. 259).

Just before the '97 economic meltdown, most investors had no problem with Indonesia's one-man show as most of its macroeconomic indicators looked sound (MacIntyre, p. 2001). As the international money flowed in, one prominent, Indonesia watcher commented that Suharto's "formula of combing economic benefits with tough authoritarian control is proving remarkably durable" (Eklof, 1999, p. 96). However, the durability of Suharto's authoritarianism seemed less secure within months of this statement as Indonesia's economy came crashing down. As the economy crumbled, all eyes turned to Suharto, and suddenly people wondered whether he had the discipline to solve the problem. In October, The Economist noted that many of Indonesia's businessmen had come to believe that "the web of patronage, cronyism, and corruption that binds the economy together prohibits effective government action" (10/11/97). While Hal Hill notes that KKN (korupsi, kolusi, dan nepotisme) did not cause the economic collapse, like corruption, collusion and nepotism had been well entrenched all through Indonesia's growth years, he does suggest that once the crisis hit, they added to the crisis and prevented the government from responding adequately (1998). MacIntyre supports this by applying his theory of veto power to Indonesia and suggesting that the lack of multiple centres of powers made investors nervous (2001, p. 112).

Not only did this centralisation of power make investors nervous, it eventually led blame for the crisis to fall at Suharto's feet. When the crisis first hit Indonesia, the world looked to Suharto for leadership, while Suharto himself looked to the International Monetary Fund (IMF), which however wise economically proved to be politically disastrous. Though the IMF provided Indonesia with a 43 billion dollar bailout, this, of course, came with strings 
attached as Indonesia was among other things required to cut its budget, raise taxes, and increase interest rates (Eklof, 1999, p. 105). This bitter medicine caused the economy to contract, leading many economists such as Stiglitz and Feldstein to claim the IMF prescription was far too harsh. Feldstein, in particular, criticised the IMF for inappropriately trying to reform Indonesia's political system by attempting to rewrite the relationship between the government and business (1998). The agreement with the IMF put the spotlight squarely on Suharto, as the package had attacked the notorious car dealership belonging to his son Tommy and some banks whose owners were closely connected to the president (Eklof, 1999, p. 106).

By early 1998, as domestic criticism mounted with the economy's continued decline, Indonesians openly questioned whether Suharto was too old for the job. In a major reversal of policy, Suharto announced an expansive budget that Eklof suggests was "designed to fend off social and political unrest in the wake of the crisis" (1999, p. 123). However, this move only served to shake international confidence and led the rupiah to fall even further, and many feared that the ageing leader was more concerned about protecting his family' $\$ 40$ billion dollar investments than in solving Indonesia's broader problems (Liddle, 1999). Suharto's policy reversal led to an hour-long phone call with President Clinton who urged him to maintain his austerity program and to the IMF threatening to hold back its payments (Pine, 1998). On January 15 in response to this pressure, Suharto reversed course again and signed a new pledge with the IMF which required Suharto to end subsidies on electricity and oil, creating an additional hardship on both the Indonesian people. The agreement was signed in a televised ceremony, "which showed the IMF director standing imperiously over the president with his arms folded across his chest" (Eklof, 1999, p. 125) an indelible image of Suharto that made him look weak and ineffective in the eyes of his people. Eklof says the event was "seen domestically as humiliating to national dignity" (1999, p. 126). Suharto was thus left in a fix: to blame the IMF would be to blame himself for his weaknesses in cowering to them; yet, the centralisation of all power under Suharto had left him alone with no one else to point to, Suharto now became identified with the problem, which undermined his main source of legitimacy, positive economic performance. Ultimately, it was a loss in confidence in Suharto that gave investors the jitters and led the economy to spiral downward until he was removed. While it is doubtful that Suharto was more or less responsible than Mahathir for his country's economic downturn, the difference, we will see, was that one had a political system that allowed for political cover while the other did not. 
By the middle of 1998, as the crisis deepened and opposition mounted, Suharto's isolation became complete. Having outlasted most of the people, he rose to power with, the new cabinet he formed following his mock re-election in 1998 consisted of his favourite daughter, Tutut, his golf buddy, and a bunch of other cronies. Likewise, his hand-picked vice president was Dr B.J. Habibie who had been Suharto's childhood friend and was chosen more for his loyalty than his skill. Eklof says the new cabinet "conveyed the impression of a lonely president appointing people around him for his trust in their personal loyalty rather than for their competence of capacity" (199, p. 155). Ultimately, Suharto was left alone to face his fall.

\section{Mahathir's Consultative Authoritarianism Faces the Crisis}

Unlike Suharto, Mahathir strongly led rather than dominated a ruling clique, which ultimately helped him survive. Mahathir was no democrat, as he ruthlessly harassed his opponents both within and outside his regime. By 1990, he had asserted dominance over the judiciary, the traditional Malaysian elite, and his opponents within the ruling political party, the UMNO (Elson, 2001, p. 30); however, he never allowed himself to become as isolated as Suharto and was more willing to share power with those who supported him, in what I choose to call consultive authoritarianism. MacIntyre, explains that "unlike Suharto, he did need to have a close regard for his position in the party because of Malaysia's parliamentary structure $(2001,112)$. However, because of this lack of total power, when the economic crisis hit, Mahathir was able to distance himself from his government's failed policies and then pose himself as an alternative and saviour to what his advisors had done wrong.

When the crisis first struck Malaysia, Malaysia's finance minister, Anwar Ibrahim, decided to take pre-emptive action by announcing a series of austerity plans to shore up the Malaysian economy in what Khoo describes as an "IMF package without IMF intervention" (2003, p. 49). Though Anwar claimed that his policy had Mahathir's approval (Khoo, 2003, p. 61), Mahathir eventually repudiated it and launched a tirade against the IMF as well as international bankers and Jews. Ultimately, he bucked the IMF by placing capital controls on Malaysia's currency. Economists to this day debate the economic soundness of Mahathir's policy; however, Khoo points out that the gains were primarily "political and ideological" (2003, p. 54). Politically, it proved viable and shrewd by deflecting blame from him. What is important to remember scapegoating Anwar was possible and credible only because 
Mahathir lacked total power and Anwar had political stature as an independent agent who could formulate and advocate his policy.

Prior to their major falling out, Mahathir had had numerous policy disagreements with Anwar. These ranged from dealing with corruption to issues of foreign policy (Elson, 2001, p. 146). However, when asked about these disputes in May of '97, Mahathir seemed comfortable with the opposition, saying "Apparently he has the support. I can't be changing deputies all the time. If you change deputies too many times, it must be because you are wrong and not them" (Elson, 2001, p. 151). Business Week likewise pointed out that "Mahathir and Anwar had long had differences over economic stewardship and management of political spoils (and) that rift widened as Asia's financial crisis wore on and the two leaders worked increasingly at cross purposes" (1998). Business Week went on outline the feud that had built up between Mahathir and Anwar for over a year as each man tried to direct the economy in a different direction. In December, Anwar even pushed an austerity plan through the cabinet just as Mahathir was calling for an expansion of the economy. It is hard to imagine a member of Suharto's regime having the chance to challenge him in this manner.

In the end, it became too much of a threat even for Mahathir, and he finally sacked Anwar on September 1, 1998, the day after he announced his currency controls. Anwar would end up being jailed and convicted for corruption and the immorality of having a homosexual affair with his chauffer. While this was a risky move for Mahathir as Anwar had a strong base of power throughout the country, it places blame for the troubled economy away from Mahathir, and unlike Suharto bowing to the IMF, Mahathir appeared strong, in control, and a symbol of national strength. Additionally, the fact that Mahathir quickly chose a new successor gave Malaysians some assurance that despite his excesses, a smooth transition would lead to a new regime. This was not the case in Indonesia where there were no other strong leaders in the regime, there had never been a smooth change in leadership, and Suharto had given no indication of who or what would follow him.

\section{Military Relations and Responding to the Crisis}

In examining power at the top, it can be seen that not only did Mahathir and Suharto differ in the relations with their advisors, they also differed in their relationship with their militaries. This too affected their fates. Suharto's deteriorating relationship with the military also contributed to his isolation and vulnerability. Historically, Indonesia's military had been governed by a 
policy of "dwifungsi" which gave it the duel function of making it the protector of both the nation's defence and domestic stability (Pintak, 1998). Max Lane writes that "If Golkar served as Soeharto's main political machinery, the Army functioned as guardian of the state. And since the state was personalised around Soeharto alone, the Army also served to protect him" (2005). However, Suharto's determination against the military's wishes to make Sudharmono his vice-president and the head of Golkar in the late 1980's left a lasting strain on the relationship. Then, in 1995, Suharto revoked 25 of the military's 100 reserved seats in the parliament (Elson, 2001, p. 265). This move further undermined one of his key bases of support and left the president more vulnerable in the end. Liddle says that Suharto, while expecting the military to back him didn't consult with them and just said, "here's my strategy, you implement it" (1998). Damien Kingsbury will, in fact, conclude that "disputes within Golkar and the armed forces, particularly over the issue of succession, contributed to Suharto's resignation" (2005, p. 104).

Ironically, Suharto's relationship with the military cut him in two ways. First, the growing rift between him and the military leadership meant he wasn't able to count on their support in the crunch of the crisis. At the same, the legacy of his closeness to the military come back to haunt him when elements within the military bully students during the protests that break out in 1998. This became clear when the student protests against Suharto gained momentum in May of ' 98 , and the military made provocative declarations. For example, when U.S. Secretary of Treasury Cohen met with armed forces commander in chief Feisal Tanjung, the general announced, "The armed forces will not hesitate to cut to pieces all anti-government groups" (Lane, 2005). In Mid-May of 1998, when campus protests against Suharto turned into deadly riots, there was widespread speculation that the violence had been instigated by certain segments of the military. Eklof suggests that whether or not the military was responsible, the rumours that they were fueled the fire against Suharto (1999, pp. 190-195). Thus, when six students were reportedly killed by soldiers on May 14, David Lamb of the Los Angeles Times reported that it was a turning point in worldwide opposition to the regime, and indeed Suharto was gone within two weeks (1998).

However, it was not only military oppression that led to Suharto's collapse, but it was also their abandonment of him. During the protests, Max Lane wrote, "The only strategy left to (the student protesters) is to hope that the economic crisis continues, causing a section of the military to break from Suharto. If this happens before the MPR meets in March to elect the president, the military might be able to force Suharto to retire" (1998). Though Lane said 
he doubted this would happen, it was indeed what happened. In fact, on May $13^{\text {th }}$ Reuters reported that "a group of retired generals voiced its support for the students and appealed to Army forces to join the movement for political reform" (1998). Eklof reports that as the student protests escalated, the government split when segments of the military urged conciliation while Suharto pressed for a hard line. This, he said, led to a perception that the government was cracking and encouraged the students to increase their actions (1999, p. 174). William Case similarly explains that "Suharto had long relied on the military, deploying it as his fire extinguisher, his 'pemadam api', disciplining labour and keeping the country together. But this dependence also meant that when the military pledged finally to withdraw its support, Suharto was left with little to stand on" (2005). Thus, when demonstrations against Suharto got out of hand, there was to be no Tiananmen Square type of crackdown in Indonesia, yet Suharto would still be blamed for military repression. In the case of the military, both Indonesia's lack of political freedom and Suharto's non-inclusive rule turned against him.

By contrast, both Case and Smith Brandon point out that in Malaysia, the military was neutral and not a political instrument used to create fear among people. The military had no role in forming or implementing policy, and Malaysia's national leaders had never used the military to prop up their rule $(2005,1998)$. While this may be the effect of the British training of the military before independence (Milne, 1997, p. 2), whatever the reason, it is significant that the military did not intervene during the street demonstrations following Anwar's arrest in a way that was politicised or led to more violence. This greater degree of liberty in Malaysia paved the way for relatively peaceful elections to take place in 1999 that would ultimately diffuse the crisis and stabilise Mahathir's continued rule.

\section{Imposed Consensus vs. the Politics of Opposition}

Whereas Suharto created a system based on imposed consensus, the Malaysian system could be described as one based on the politics of opposition, for not only did Suharto and Mahathir differ in the degree they empowered and relied on those closest to them, they also differed in how they incorporated opposition parties into their system of authoritarianism. This too will contribute to their differing fates. 


\section{Indonesia's One Party Machine vs. Malaysia's Contested Power}

When General Suharto took over Indonesia in 1969, he required the 16 existing political parties to consolidate themselves into three parties, including Golkar, his political machine. These parties were created, however, more to provide some legitimacy for the regime by creating a semblance of democracy and a forum for limited debate rather than to pose any real opposition to Sukarno's rule. As Elson says, "their role was to advance the national interest, not to contest it" (2001, p. 306). Damien Kingsley points out that the parties had to be officially sanctioned and their range of activity was circumscribed (2002, p. 103), while the Jakarta Post online history suggests elections were held simply "to gain the political legitimacy (which was) perceived as a prerequisite to economic growth" (2006). Likewise, The New York Times reporting on the 1997 parliamentary elections which paved the way for Suharto's seventh term, described them "as more ritual than substance" noting that the government "sought to control every aspect of the vote" (Mydans, 2005). Smith Brandon explains that while opposition political parties existed under Suharto, in truth, they had very little power. People did not vote for president, and only elected half of the legislature (the MPR), which then selected the president. The other 500 members of MPR were appointed by the president or reserved for the military (Smith Brandon, 1998). This structure did not allow for challenges to Suharto, and under this system, Suharto was unanimously elected president six times out of six.

From the beginning, the Malaysian political system, on the other hand, was characterised by opposition groups that contested the UMNO's leadership and hegemony as well as by major factions within the UMNO (Elson, 2001, pp. 39-44). Whereas Suharto was initially installed by the military and only was Indonesia's second leader, Mahathir was Malaysia's fourth Prime Minister and rose to power through a contested electoral process. While there is no doubt that as Mahathir amassed power, he became more and more authoritarian, Malaysia's electoral history could never be fully erased. This is not to say that he has been friendly to political opponents. The BBC online reports that "In 1987, a challenge to Mahathir's leadership led to mass detentions of his critics under the Internal Security Act and the sacking of judges he deemed too interfering" (1999). Likewise, the media was strictly controlled, and journalists were frequently jailed (Elson, 2001, p. 113).

While Malaysia could not have been considered a bastion of democracy, its institutions were at least grounded in a democratic process. Mahathir and his ruling UMNO party were elected by the people in freely 
contested elections and needed to maintain its coalition, the Barisan National (BN), to hold onto power (MacIntyre, 2001). Although the UMNO dominated Malaysian politics, opposition groups occasionally presented serious challenges to Mahathir's rule, and the political process in Malaysia was relatively free and opens (Smith Brandon International, 1998).

\section{The Breakdown of Indonesia's Pseudo-Democracy}

Despite his firm grip on power, Suharto could not hold onto it when the system came under intense pressure. A challenge to Golkar's solo rule came in 1996 when the PDI (Indonesian Democratic Party) considered making Megawati Sukarnoputri (Sukarno's daughter) a candidate for the presidency in 1998. However, just the thought that he would be opposed was so distasteful to Suharto that he intervened to have Megawati sacked from the party. This was accomplished when government forces called for a sham PDI Congress to which none of Megawati's supporters was invited (Eklof, 1999, pp. 29-38). The transparency of Sukarno's role in Megawati's disposal was so blatant that student demonstrations broke out across Indonesia culminating in "Grey Saturday" on July 27, 1996, when a demonstration of 10,000 broke into a bloody and violent riot. While Suharto emerged from the affair relatively unscathed, Eklof indicates that the event signified that young people and others "lacked adequate channels for their social and political aspirations" (1999, p. 49). While at the time of Megawati's ouster, the opposition lacked the clout to start a popular movement, according to Eklof, the ousting of Megawati in '96 set the stage for a broad movement that drove Suharto from power when the crisis hit a year later.

The deeper roots of the political frustration of the young and the resulting instability of the Suharto dictatorship can be found in the economic development that, ironically, Suharto himself created for Indonesia. When Suharto came to power in 1966, annual per capital income was only $\$ 70$ (Kristof, 1998); however, by 1997 this had risen to $\$ 3,770$ (CIA Fact Book, 1997). This growth represented a massive shift in culture and society that had not been mirrored by corresponding political changes. While the public may have been tolerant of the one-man rule while they were struggling to survive, middle-class values suggested a more open system. In 1998, The Economist reported that compared to the Sukarno years:

Indonesia has a deeper stratum of educated, younger reformists, who have chafed at the restrictions and injustices of one-man rule. Under Mr Suharto, 
they went into business, academia, the bureaucracy or a plethora of nongovernmental organisations, and pondered, interminably, the looming succession crisis. "If only we had an Anwar!" is how one, now in government, recalls their conclusions.

$(10 / 10 / 98)$

Unfortunately, there was no room in the Indonesian system for an Anwar. David Lamb notes that one of the great ironies of Suharto's downfall is that his proudest achievement was the excellent education system that enrolled 2.5 million students in universities, yet he became perplexed as to why these very people turned against him (1998). However, as Kristoff pointed out, "Young people chattering on cell phones under McDonald's Golden Arches in Jakarta do not want a traditional Javanese king (1998). Even in 1995, when the economy was cooking along, some journalists such as Michael Shari foresaw trouble brewing. He pointed out that while the middle class never had it better, there was more and more "grumbling" and suggested that Suharto might have to "accommodate a slightly more open system (1995). Eklof points out that by the mid-1990's the growing number of "politically educated Indonesians" were already "feeling that the Suharto era was approaching its end" and was fed up the rigged elections and constant corruption. He ultimately concludes that it was the incapacity of Suharto's political system to accommodate the social progress he engineered that brought him down (1999).

The Jakarta Post's web history of Indonesia explains that over his reign Suharto disfranchised all the significant groups in Indonesian society, pointing out that historically there had been four major ideological groupings with a real base in Indonesian society, including the modernist Muslims, the traditionalist rurally based Muslims, the Sukarnoist nationalists and the social radicals. It goes on to say that by 1997, "those four groups were more or less represented by organisations only outside the formal structure" such as the Muhammadiyah, the Nahdatul Ulama, and the PDI (2006). In the months after Suharto's infamous bowing to the IMF, there was a feeble attempt by the leaders of these three groups, Rais, Wahid, and the ousted Megawati, to take a stand against Suharto when Amien Rais reached out to Megawati and Wahid to form an alliance to try to prevent Suharto from standing for a seventh fiveyear term. According to Lane, "Wahid declined the offer, stating that any attempt to build an alternative political centre would provoke the military into repressive action" (2005). Eklof adds that Suharto's success in ousting all three from all formal positions of political influence gave them "no chance of being nominated as contenders in the presidential election (1999, p. 130). Thus, with 
opposition to Suharto was kept out of legitimate avenues of power and confined to protests on campuses around the country, on January 20,1998, Suharto was nominated by the MPR without opposition, making Suharto's unanimous re-election a "foregone conclusion" (Eklof, p. 131).

However, the nomination brought no stability, for in the month that followed riots broke out on campuses across Indonesia. On February 2 the San Francisco Chronicle noted that at the Technological Institute in Jakarta, students staged a mock trial in which they condemned Suharto to death and burned him in effigy. During the same month in Medan, 200 students were detained and 15 injured when police fired on them as they demanded that Suharto stands down. While the poor may have been more concerned about economic issues, the banners carried these protesters read "Democracy" not "Economic Justice" (Torchia, 2/2/98, 23/20/98).

By March 10 when the MPR formally elected him, over 100 people had been killed just in the riots in Jakarta (Kingsbury, 2002, p. 231), making his victory hardly a referendum of democracy. The Jakarta Post's story the next morning reflected the meaningless of the election and just how isolated the regime was from the rest of society. It ran:

Although before the Assembly convening there had been a lot of popular anger at rising prices, it was all quiet on the Jakarta front during the General Session. The Session ran successfully and smoothly ... But what should define success in a democratic country? Two theatres have staged political activity in Indonesia in recent days. One is the Assembly, which has met daily since March 1 . The other is the university campuses which have been the scene of student rallies demanding essential economic and political reform to solve the crisis gripping the country.

Regretfully, we have only seen a massive chasm between the two political stages. The Assembly members were too busy to pay attention. They failed to recognise that the student demands are crucial to the future of this nation. Soeharto will shortly appoint his new cabinet. We must now wait to see whether it proves capable of healing the nation's wounds if ointments are applied only to the economic sector.

As noted earlier, the new cabinet did nothing to restore confidence in the Regime, and within twelve weeks, after more than a 1,000 lives and millions of dollars of property destruction, Suharto was driven from power (Schwaab, 1999). 


\section{A Legitimizing Election in Malaysia in the Midst of Crisis}

Whereas Suharto's mock re-election in 1998 served to unravel the country, the election held in Malaysia in the midst of the crisis in 1999 served to bring some stability to his country. While Malaysia's election may not have been democratic by Western standards, it did provide a forum where opposition groups could truly contest the UMNO's hegemony and while the UMNO maintained its dominance of the country, the fact that they lost seats in the parliament and even control of some provinces gave legitimacy to the election and ultimately helped the regime stay in power.

Mahathir's dumping of Anwar was similar to Sukarno's ousting of Megawati from the DPI as both had the goal of pre-empting a potential opponent. However, Mahathir's case seemed even riskier as it took place in the midst of the economic crisis rather than a year before it. Indeed, Anwar's arrest, detention, and apparent physical abuse resulted in student demonstrations across Malaysia. Through the months of Anwar's detention and trial, students, echoing their counterparts in Indonesia shouted "Reformasi", the name of the movement that had brought down Suharto. Galvanizing around Anwar's wife, Wan Azizah, they called for Mahathir's resignation; however, ultimately the population's frustration and anger resulted, not in a people's revolution as in Indonesia, but rather in an electoral response which left Mahathir in power. Indeed, in reply to those who suggested that the protests might bring down his government, Mahathir responded that "He (Anwar) wants to bring the government down by demonstrations, as happened in Indonesia. This is not Indonesia, and I am not Suharto" (Mahathir, 1999). Mahathir had a point. In the end, it was the viability of a genuine electoral process that allowed Mahathir to survive as the protesters settled for a contested election rather than a revolution, an option that was non-existent in Indonesia.

Unlike Suharto's coronation by the MPR in 1998, which simply was written off as a sham, Mahathir's re-election revived his legitimacy because there was a true belief that he could have lost. As the elections approached in 1999, the loose movement that had supported Anwar formed itself into a political coalition to challenge the UMNO (Khoo, 2003, p. 100). The new organisation known as the Barisan Alternatif (BA) or the Alternative Front, consisted of an alliance between three main opposition parties: the longstanding Islamic PAS, Chinese-dominated DAP, as well as the PKN, which was new the pro-Anwar party. Khoo acknowledged the election took place on a "non-level playing field" as the press, mass media and state machinery were 
all controlled by Mahathir's BN coalition. In fact, police disrupted rallies, and thousands of voters were purged from the electoral rolls (Teik, 2001 261). However, the UMNO's victory was never considered a given, and in the end, Khoo calls it an "ongoing endorsement of Mahathirism" (2001, p. 262). The BN barely maintained its 2/3 majority in parliament, and thus, he says, "it seems fourteen months of tumultuous dissent had challenged the hegemony of the Mahathirist regime only to force no more than small cracks in its bedrock of stability" (2003, pp. 120-121). The victory wasn't complete, however, as, the UMNO lost 17 of its 88 seats in parliament and control of a couple of state governments (Khoo, 2003, p. 262). The surprising final result as the BBC online put it was that "The Asian financial crisis - which deposed President Suharto of Indonesia, led to changes of government elsewhere, and plunged Malaysia into its deepest recession - has only consolidated (Mahathir's) grip on power" (1999).

Samuel Huntington in The Third Wave pointed out that when authoritarian regimes hold elections in response to crises, they usually lose (1991). He goes on to show that three possible variables usually account for the exceptions which allow largely non-democratic regimes to endure. The first is when the opposition leaders are not adequately distanced from the former regime. Second, is the presence of corruption and fraud. Third, is when the population has not reached the socio-economic level he sees as necessary for effective democracy. However, in Malaysia, none of these factors existed. Though there was no international presence to monitor the Malaysia's election, the results were never contested, and there was no indication of widespread fraud. Though Anwar had been part of the Mahathir regime, the movement his arrest had sparked clearly had made a break with the past and included long-standing opposition groups. Finally, Malaysia was certainly richer than Indonesia and had surpassed the \$3,000 per capita GNP that made it a high candidate for democratisation according to Huntington's standards (1991, p. 62). Indeed The Economist wrote:

The outrage his treatment of Mr Anwar has caused at home is in part the result of the success-at least until last year-of his economic policies. A new Malaysian middle class is no longer willing to believe all the government tells it. And a basic sense of justice has been offended.

(10/10/98)

In reality, as will be shown in the following section, the opposition's defeat can be best attributed to its internal divisions and thus its failure to unseat 
Mahathir and the UMNO re-legitimised the regime and gave it new life, bringing to an end the uncertainty about Malaysia's immediate political future. Economist Dani Rodrick shows that countries with democratic regimes respond better to economic crises (1999, p. 82), and it indeed seems that Malaysia was just democratic enough that the election helped restore confidence in the regime and contributed to its success as well as Malaysia's economic recovery. This stands in sharp contrast to Indonesia where the political process added to scepticism further debilitating the economy and ultimately resulting in Suharto's collapse.

\section{The Politics of Division vs. the Politics of Unity}

In the final act of the dramas in both Malaysia and Indonesia, the regime's relationship to their ethnic minorities proved to be decisive. In Malaysia, it was the Chinese vote that put Mahathir's UMNO over the top, while in Indonesia, Suharto's scapegoating of the Chinese led to the spiralling violence that toppled him.

\section{The Politics of Race - Indonesian Style}

From the beginning, Suharto tried to play the races off each other. On one level, he favoured the Chinese by allowing them to dominate the biggest sectors of the economy. Lane notes that "Some businesspeople, many of whom were of Chinese descent, enjoyed state protection and sometimes twodigit economic growth; some grew to become tycoons and magnates" (2005). However, Lane and others note that the privileges these businesspeople enjoyed sparked resentment from Malay majority. This is understandable because the Chinese while constituting only 3\% of the population controlled $70 \%$ of Indonesia's wealth (Gecker, 1998). Eklof suggests Suharto turned to the Chinese because their racial status prevented them from ever being a serious political threat despite their wealth (1999, p. 12), However, for Chinese at large, this meant they became targets of ethnic resentment, something Suharto never seemed to try to forestall and in fact once the crisis hit may have even promoted (1999, p. 152). William Case states "this also helped to fuel social tensions, exploding finally in the Jakarta rioting. A great irony, then, is that while Suharto remained insulated from the Chinese, the attacks they then suffered created such disorder that they helped, in the end, to undermine him (2005). In the month before Suharto's fall, ethnic riots broke out that left some Chinese dead and destroyed hundreds of Chinese businesses (Geeker, 1998). 
The Economist suggested that these riots may have been incited by the government for the purpose of diverting blame from the regime, writing that "senior government officials have tried to deflect blame for the economic crisis on to prominent members of the ethnic Chinese community" (10/10/98). If this was the government's intention, it backfired when the violence snowballed and got out of hand and led to Suharto's early departure. With Chinese business men fleeing the country with their families, international investors became even more nervous, the economy sagged, and a consensus for Suharto's ouster came to be supported by the international investment community, the Indonesian military, and broad segments of the middle class (Eklof, 1999, pp. 109-110).

\section{Malaysia's Struggle to Find Ethnic Balance}

In Malaysia, the ethnic situation was handled quite differently. Mahathir worked for years to bridge the economic gap between Malays and Chinese whose average income was twice that of the Malays through the NEP (New Economic Policy) which promoted the economic development of the Malay population though affirmative action programs and economic assistance in education (Elson, 2001, p. 17). This had the positive effect of lessening the anger that had been directed towards the Chinese and eased the resentments that had fuelled ethnic rioting in 1969 (Elson, 2001, p. 57). In describing his attitude toward managing Malaysia's ethnic divide, Mahathir himself suggested:

Democracy is a tool to bring together groups of people with different interests, to discuss problems and to decide matters with the approval of the majority. The important thing is that minority groups should be represented and protected and their interests are taken into consideration.

$(1999,55)$

It was reasonable for Mahathir to think along these lines for the Chinese made up 30\% of Malaysia's population while Indians consisted of another $10 \%$; even in a pseudo-democracy, these are significant numbers to reckon with. When the economic crisis hit and Mahathir tried to shift the blame from local entrepreneurs to international forces, such as currency traders and fund managers, he not only absolved Malay entrepreneurs but also shielded the wealthy Chinese from social resentments as had occurred in Indonesia. 
In the early 90s, Mahathir came out with Vision 2020 program, which began to phase out the affirmative action programs that had favoured the Malays. He believed that because of the advances the Malays had made over the past decades it was time to do away with the programs giving them special advantages. His stated goal was to create a unified Malaysia where ethnic background would no longer be an issue (Milne, 1997, p. 165). With this in mind, it is understandable how Mahathir's electoral victory in 1999 owes much to the support he got from the Chinese community. Smith Brandon reported that Mahathir preached racial harmony, cooperation and stability as keys for long-term economic growth and prosperity. At the same time used the Indonesian crisis to stir fears among Chinese about the potential for ethnic violence to gain their political support (1998). Because the opposition BA coalition included a strained alliance of the PAS, a religious Islamic party, and the largely Chinese DAP, some Chinese leaders urged support for Mahathir by claiming that a vote for the Chinese DAP is a vote for the Muslim PAS (Lane, 2005). Mahathir exploited this by using the media to play up that a PAS victory would mean renewed ethnic violence and an Islamic state; perhaps because of this even the neutral Malaysian Council of Buddhism, Christianity, Hinduism, and Sikhism, showed its support for Mahathir's BN, which was a big blow for the BA (Khoo, 2001, p. 261). In the final analysis, Mahathir's history of recognising the needs of the Chinese as well as the Indians helped to save him, while Suharto's game of playing the races off each other created violence that helped to up-seat him.

\section{Conclusion}

In the final analysis, Suharto fell while Mahathir survived because his regime was less free and inclusive. When the Indonesian economy collapsed, blame was placed squarely on his shoulders, and his mere presence led the economy to further deteriorate. Furthermore, by silencing all opposition, opponents had no outlet for their frustrations other than street demonstrations led by middleclass students that could no longer tolerate Suharto's old style rule. Finally, as these demonstrations spread to the poorest segments of society, they erupted into an orgy of ethnic violence that made his regime untenable, and with even the military no longer in his inner circle, Suharto had no one to turn to. When the crisis hit Malaysia, on the on the hand, Mahathir found himself in a very different position. First, because his brand of authoritarianism was more collective, he could deflect criticism for Malaysia's economic troubles to his subordinates. Also, because the system allowed for a real contest for power, 
groups frustrated with his leadership could mount an electoral challenge rather than simply resort to destabilising and escalating street demonstrations. The demonstrations that did occur were contained by a military that was not tarnished by years of repression and political interference. Finally, Mahathir was able to win an election that posed a true challenge to him due to his long history of acknowledging the needs of minority groups within Malaysia.

Ironically, Indonesia's relative lack of freedom in 1997 may account for its being freer than Malaysia is today. Indonesia's greater level of freedom is confirmed by Freedom House, which rates Malaysia as more free before the crisis, yet rates its behind Indonesia in 1998, a relative position it maintains up to the present (See Fig. 3). Indeed, since Suharto's fall, Indonesia has had three successful political elections and presidents from some political parties. While corruption is rampant and the judiciary is problematic, the country has made much progress towards democratisation. In Malaysia, following his electoral victory, Mahathir worked to firm up his control, which had been weakened by the 1999 election. In 2000, dissidents were jailed, and journalists were muzzled, leading The Economist to lead with the headline, "Another crackdown on the Opposition in Malaysia" (1/22/00).

Fig. 3

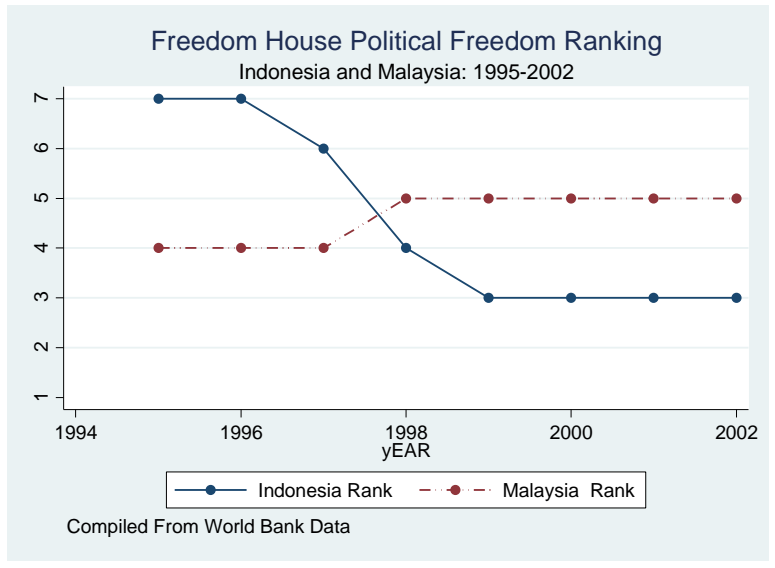

Though Mahathir retired in 2003, the UMNO is still in control, and his legacy of authoritarianism lives on. Perhaps the crisis beginning in 1997 created a window of opportunity for change that only Indonesia was able to capitalise on due to its greater lack of freedom and Suharto's determination to maintain him as the complete centre of power. While at the time of his fall it was not certain that a more democratic system would replace Suharto, it has 
come to be. Perhaps Malaysia is under Mahathir up to now still authoritarian enough for the economic crisis to bring real change.

In this regard, we believe that the Malaysians understand and are aware that history has proved to them that the eternal is the change itself. We saw, in their way, the people of Malaysia are doing reform, and they are welcoming the changes.

\section{Endnotes}

${ }^{1}$ The ringgit dropped from about 2.5 per dollar before the crisis to nearly 5 to one in January of ' 98 , in six months the rupiah fell from 2,200 to the dollar just before the crisis.

2 World Factbook data on this shows that, before 1997, in Indonesia, the lowest $10 \%$ and highest $10 \%$ owned $3.6 \%$ and $30 \%$ of the wealth respectively, while these figures for Malaysia were $1.4 \%$ and $20.5 \%$. These differences persisted through the crisis as the Gini index measured for 2002 showed Indonesia to have a more equitable 31.7 rating compared to Malaysia's 49.2 rating.

\section{References}

Asiaweek. (1997). Cover Story: The Top Fifty. p. 32-38.

Aspinall, E., van Klinken, G. A., \& Feith, H. (Eds.). (1999). The last days of President Suharto (No. 49). Monash Asia Institute.

BBC (1999, November 10). Malaysia's strongman Mahathir. Retrieved from http://news.bbc.co.uk/1/hi/special_report/1998/10/98/malaysia_crisis/17 2813.stm.

Borthwick, M. (1992). Pacific Century. San Francisco: Westview Press

Case, W. (2005). Why Mahathir will not go the Way of Suharto. School of International Business Griffith University Asian analysis by the Asean Focus Group of the Australian National University. Retrieved from www.aseanfocus.com/asiananalysis/article.cfm?articleID $=65$.

Eklof, S. (1999). Indonesian Politics in Crisis. Copenhagen, Denmark: Nordic Institute of Asian Studies.

Elson, R. E. (2001). Suharto: A Political Biography. New York, NY: Cambridge. Feldstein, M. (1998). Refocusing the IMF. Foreign Affairs, March/April.

Felker, G. (1998). Malaysia in 1998: A Cornered Tiger Bears its Claws. Asian Survey 39:43-54. 
Freedom House. (2005). Freedom in the World Comparative Rankings: 1973$2005 . \quad$ Retrieved from www.freedomhouse.org/template.cfm?page $=15 \& y e a r=2005$

Geeker, J. (1998). Ethnic Chinese Bearing Brunt of Indonesia's Anger. San Francisco Chronicle. 5/11/98 p. A16. Originally in AP. Retrieved from personal archives.

Hill, H. (1998). The Indonesian economy: the strange and sudden death of a tiger. In The Fall of Soeharto ed. Geoff Forrester and R.J. May. NY: Crawford House Publishing.

Hilley, J. (2001). Malaysia: Mahathirism, Hegemony, and the New Opposition. New York: St. Martin's Press.

Huntington, S. (1991). The Third Wave: Norman, OK: University of Oklahoma Press.

The Jakarta Post Online. (2005). History of Indonesia. Retrieved from www.thejakartapost.com/history/history.asp.

The Jakarta Post. (1998). Political Reforms more Imperative than Ever. The Jakarta Post.

Jakarta Post. (2005). After this what next? Retrieved from http://0proquest.umi.com.opac.sfsu.edu/pqdweb?index $=3 \&$ did $=270839$ $97 \&$ SrchMode $=3 \&$ sid $=5 \&$ Fmt $=3 \&$ VInst $=$ PROD $\& V T y p e=P Q D \& R Q T=30$ 9\&VName=PQD\&TS=1134932529\&clientId=17866\&aid=4 .

Jakarta.

Retrieved

from

http://0proquest.umi.com.opac.sfsu.edu/pqdweb?index $=24 \&$ did $=25534$ $506 \&$ SrchMode $=3 \&$ sid $=2 \&$ Fmt $=3 \& V I n s t=P R O D \& V T y p e=P Q D \& R Q T=3$ 09\&VName=PQD\&TS=1134931351\&clientId=17866\&aid $=3$.

Kingsbury, D. (2002). The Politics of Indonesia. New York, NY: Oxford University Press

Kristof, N. (1998). Suharto Seen as an Anachronism in New Asia. San Francisco Chronicle. 5/17/98. Originally in New York Times. Retrieved from personal archives.

Lamb, D. (1998). Students Death Could Be a Turning Point. San Francisco Chronicle. 5/14/98. Originally in Los Angeles Times. Retrieved from personal archives.

Lane, M. (2005). Suharto on the brink. The Green Left Weekly. Retrieved www.greenleft.org.au/back/1998/318/318p3.htm.

Liddle, R. W. (1998). Crisis in Indonesia. Speech was given at the World Affairs Council of Northern California. (Transcript from personal archives). 
Liddle, R. W. (1999). Indonesia's Unexpected Failure of Leadership. In Adam Schwarz and Jonathan Paris (ed). The Politics of Post-Suharto Indonesia. NY: Council on Foreign Relations Press.

MacIntyre, A. (2001). Institutions and Investors: The Politics of the Economic Crisis in Southeast Asia. International Organization Vol. 55, No. 1 pp. 81-122.

Mahathir, M. (2004). Achieving True Globalisation. Subang Jaya, Malaysia: Pelanduk Publications.

Milne, R. S., \& Diane, K. M. (1999). Malaysian Politics under Mahathir. New York, NY: Routledge.

Mohamad, M. \& George, S. (1999). I am not Suharto or the Shah of Iran. NPQ: New Perspectives Quarterly. 16: 8- 10.

Mydans, P. (2005). In Indonesia, Election is a Peculiar Ritual. San Francisco Chronicle. 5/29/05. p. A11. Originally in the New York Times. Retrieved from personal archives.

Pine, A. (1998). US Officials Press Indonesia to Obey IMF Plan. San Francisco Chronicle. 1/12/98. p. A10 (Originally in Los Angeles Times). Retrieved from personal archives.

Pintak, L (1998). Army Calls the Shots. San Francisco Chronicle. 3/12/98.

Prasso, S. \& Mark, C. (1998). Malaysia: The Feud. Business Week. Retrieved from www.businessweek.com/datedtoc/1998/981109.htm

Reuters. (1998). Ten More Die in Indonesia. San Francisco Chronicle. 5/13/98. Retrieved from personal archives.

Rodrick, D. (1999). Making Openness Work. Baltimore, MD: John Hopkins University Press.

Santoso, A. (1998). Democratisation: The Case of Indonesia's New Order. In Anek Laothamatas, ed. Democratization in Southeast and East Asia. NY: St. Martin's Press. pp. 21-45.

Schwarz, A. (1999). The Politics of Post-Suharto Indonesia. Council on Foreign Relations Press: New York, NY.

Shari, M. (1995). The Years of Growing Furiously. Business Week. 11/6/1995, p. 160.

Smith Brandon International (1999). Malaysia: Another Indonesia? 1 (1). Retrieved from www.smithbrandon.com/report.aspx?id=49.

Stiglitz, J. (2000). The Insider: What I Learned at the World Economic Crisis. The New Republic. April $17 \& 24$.

Khoo, B. T. (2001). Malaysia Mahathirism: Hegemony and the New Opposition. New York, NY: Zed Books Ltd. 
Khoo, B. T. (2003). Beyond Mahathir: Malaysian Politics and its Discontents. New York, NY: Zed Books Ltd.

The Economist. (1997). And Now for Indonesia. (10/11/97), p. 21.

The Economist. (1997). Not Fair. (7/26/1997) p. 16.

The Economist. (1998). Out with the Old, in with Something much less Familiar. (10/10/98) Vol. 349, Issue 8089, p. 21.

The Economist. (2000). Vengence is Mahathir's: Another Crackdown in Malaysia. 354 (8154), p. 19.

Torchia, C. (1998). Indonesian Student Protests Spread. San Francisco Chronicle. 2/2998. Originally in AP. Retrieved from personal archives.

Torchia, C. (1998). Indonesian Students Yelling in the Wind. San Francisco Chronicle. 3/20/98. Originally in AP. Retrieved from personal archives. Warshaw, S. (1990). Southeast Asia Emerges. Berkeley, CA: Diablo Press 